\title{
The Effect of Moringa oleifera as a Primary Treatment in Urban Wastewater in Martínez De La Torre, Veracruz
}

\author{
M.A. López-Ramírez†*, C. Argüelles-López**, M.R. Aguilar-Rodríguez*, J. Barragán-Díaz***, \\ O.P. Castellanos-Onorio $* * * *$ and F. Lango-Reynoso $* * * * *$ \\ *Department of Environmental Engineering, Tecnológico Nacional de México/Instituto Tecnológico Superior de \\ Martínez de la Torre, Ignacio de La Llave 182, Centro, 93600, Martínez de la Torre, Veracruz, México \\ ***Department of Business Management's Engineering, Tecnológico Nacional de México/Instituto Tecnológico Superior \\ de Martínez de la Torre, Ignacio de La Llave 182, Centro, 93600, Martínez de la Torre, Veracruz, México \\ ***Department of Industrial Maintenance, Engineering Universidad Tecnológica de Gutiérrez Zamora, Prolongación Dr., \\ Miguel Patiño s/n, Centro, 93556 Gutiérrez Zamora, Veracruz, México \\ ****Department of Chemical-Biochemical Engineering, Tecnológico Nacional de México/Instituto Tecnológico de \\ Veracruz, Calzada Miguel Ángel de Quevedo 2779, Formando Hogar, 91897, Veracruz, Veracruz, México \\ ******Department of Postgraduate and Research, Tecnológico Nacional de México/Instituto Tecnológico de Boca de Río, \\ Carretera Veracruz-Córdoba Km.12, 94290. Boca del Río, Veracruz, México \\ †Corresponding author: M.A. López-Ramírez; malopez@ tecmartinez.edu.mx
}

Nat. Env. \& Poll. Tech.

Website: www.neptjournal.com

Received: 16-04-2021

Revised: 14-05-2021

Accepted: 08-06-2021

Key Words:

Moringa oleifera

Coagulant

Primary treatment

Urban wastewater

\begin{abstract}
Wastewater treatment is a priority, as most of this is discharged into rivers, lakes, seas, and soil. Since there is no treatment facility in Martnez de la Torre, Veracruz, these fluids are released straight into the Filobobos River without treatment. Hence, the Moringa oleifera seed was evaluated as a primary treatment. In this study using wastewater from a direct discharge, $\mathrm{pH}$, turbidity, total suspended solids, and conductivity were determined as control measures. In the jar test, the treatments were carried out using different amounts of coagulant salts (aluminum and iron sulfate) and moringa powder; starting the agitation at $120 \mathrm{rpm}$ for 5 minutes and immediately it was reduced to $60 \mathrm{rpm}$ in 10 minutes with a rest time of 1 hour. After that, the quality parameters were analyzed. The moringa coagulant achieved an average maximum reduction of 71.84 per cent and 89.36 per cent in turbidity and Total Suspended Solids, respectively, which was higher than the salts used. Furthermore, its application had no effect on $\mathrm{pH}$ and conductivity parameters, and the coagulant based on Moringa oleifera as a primary treatment agent, since these qualities do not alter and post-treatment is not required, as in the case with salts.
\end{abstract}

\section{INTRODUCTION}

Water is the most significant resource in this study and our daily lives, and its availability is decreasing as a result of physical, chemical, and/or biological contamination, which degrades quality and has an impact on health, social, technical, and economic development.

Currently, research into better processes and the elimination of contaminants that impair water quality is of the utmost importance; one of these processes is the improvement in coagulation, using natural agents which can reduce the process and the cost of operation.

As a result, the need to detoxify effluents is becoming increasingly essential, necessitating the search for innovative solutions based on research into various water treatment methods that enable improved quality and adequate protection of water resources. Table 1 shows typical pollutants in wastewater.

The advantages of using natural methods for the treatment of domestic wastewater are: the implementation of relatively simple technology, low operating and investment costs, low energy consumption, the treatment process can be adapted quickly, achieving a high level of performance after the start of operations, and high nutrient removal (Rozkosný et al. 2014) since they possess a complex chemical structure, which generally consists of various types of polysaccharides and proteins. Some of them have coagulating or flocculating qualities, and in many places, the natives use them scientifically to purify murky water with excellent results (Vásquez 1994). Among the group of known substances that possess these binding properties are some organic compounds of plant origin, which can be obtained from the stem or seeds 
Table 1: Contaminants in water.

\begin{tabular}{|ll|}
\hline Class & Examples \\
\hline $\begin{array}{l}\text { Suspended solids } \\
\text { Organic matter }\end{array}$ & $\begin{array}{l}\text { Rubbish, water erosion, powder, and colloids. } \\
\text { Organic chemicals and organic residues like lees } \\
\text { or sediment. }\end{array}$ \\
Dissolved ionics & Heavy metals, nitrates, carbonates, chlorates. \\
Microorganisms & Pathogens, viruses, and parasites \\
Gases & $\begin{array}{l}\text { Methane, carbon monoxide, carbon dioxide, and } \\
\text { sulfide }\end{array}$ \\
Other & Micro plastic, medicines, and colorants \\
\hline
\end{tabular}

of a huge variety of plants such as beans, corn, Moringa oleifera, among others (Norde 2011).

\section{MATERIALS AND METHODS}

Twelve urban residual water samplings were made from a direct discharge located in the eastern coordinates: 703 632.2, North: 219480.1 Zone: 14 hemispheres: North; As can be observed in Fig. 1, the discharge of residual water is continuous during February and May, as the dry season in Martnez de la Torre is anticipated during these months. Each sample was tested for $\mathrm{pH}$, conductivity, turbidity, Biochemical Oxygen Demand in Five Days (BOD5), Total Suspended Solids (TSS), Fats and Oils, Fecal and Total Coliforms, Total Nitrogen, and Ammoniacal Nitrogen, following the Techniques outlined in the Standard Methods (APHA-AWWA-WPCF 1998).

Because the residual water in the jar test had sediment particles, the dose of coagulants 300, 600, and $900 \mathrm{mg} . \mathrm{L}^{-1}$ in a multiple agitation equipment for $5 \mathrm{~min}$ at a revolution of $120 \mathrm{rpm}$ and then $10 \mathrm{~min}$ at $60 \mathrm{rpm}$ in the jar test, leaving to stand and settle for one hour to obtain coagulation and a better reading of data. Since documented data such as those of Solís-Silvan et al. (2012) show that chemical coagulants such as iron sulfate and aluminum sulfate have an ideal floc formation range of 6.0-8.0, the $\mathrm{pH}$ was used without dampening the water for this operation.

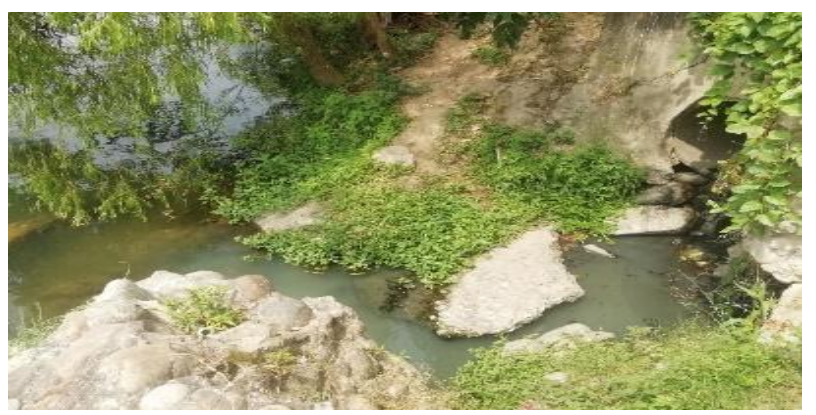

Fig. 1: Wastewater discharge point.
To determine the optimal doses of the coagulation-flocculation process, 3 doses were tested for each coagulant (300, 600 , and $900 \mathrm{mg}$ ) evaluated in triplicate. In jar testing, tests were conducted on leftover water that had been exposed to the coagulation process. The turbidity removal, measured in NTU, was used to evaluate the results. The results were compared with the different coagulants to determine the most effective one. In addition, parameters such as $\mathrm{pH}$ and conductivity were monitored.

The reduction of Turbidity was determined by the $\mathrm{HACH}$ 2100AN team performing 27 tests: 9 using Moringa oleifera powder in the coagulation process, 9 using industrial grade aluminum sulfate, and 9 with reactive grade iron sulfate heptahydrate; with doses of 300, 600, and $900 \mathrm{mg} . \mathrm{L}^{-1}$ of each coagulant.

The results of the optimal dose were subjected to an analysis of a statistical mean test with a confidence level of $95 \%$, and the same statistical method was performed for the conductivity and hydrogen potential parameters.

\section{RESULTS AND DISCUSSION}

\section{Results}

Table 2 shows the findings of the residual water characterization, and Table 4 lists the treatments that were performed to find the best coagulant doses. The clearance efficiencies

Table 2: Characterization of the wastewater generated in Martínez de la Torre, Veracruz.

\begin{tabular}{|lllll|}
\hline Parameter & Unit & Average & $\begin{array}{l}\text { Mini- } \\
\text { mum }\end{array}$ & Maximum \\
\hline $\mathrm{pH}$ & $\mathrm{pH}$ Units & 7.77 & 7.65 & 7.9 \\
$\begin{array}{l}\text { Conduc- } \\
\text { tivity }\end{array}$ & $\mathrm{mS} . \mathrm{cm}^{-1}$ & 638.67 & 636.00 & 642.00 \\
$\begin{array}{l}\text { Turbidity } \\
\text { BOD }\end{array}$ & $\mathrm{NTU}$ & 25.00 & 36.70 & 16.90 \\
$\begin{array}{l}\text { TSS } \\
\begin{array}{l}\text { Fats and } \\
\text { oils }\end{array}\end{array}$ & $\mathrm{mg} \cdot \mathrm{L}^{-1}$ & 56.60 & 54.50 & 58.00 \\
$\begin{array}{l}\text { Nitrogen } \\
\text { Total }\end{array}$ & $\mathrm{mg} \cdot \mathrm{L}^{-1}$ & 49.70 & 20.00 & 112.00 \\
$\begin{array}{l}\text { Ammo- } \\
\text { niacal }\end{array}$ & $\mathrm{mg} . \mathrm{L}^{-1}$ & 13.31 & 13.10 & 13.45 \\
$\begin{array}{l}\text { Nitrogen } \\
\begin{array}{l}\text { Fecal Coli- } \\
\text { forms }\end{array}\end{array}$ & $\mathrm{NMP} .100 \mathrm{~mL}^{-1}$ & 4600.00 & 4600.00 & 4600.00 \\
$\begin{array}{l}\text { Total Coli- } \\
\text { forms }\end{array}$ & $\mathrm{NMP} .100 \mathrm{~mL}^{-1}$ & 24000.00 & 24000 & 24000.00 \\
\hline
\end{tabular}

Source: Author 
of turbidity and TSS obtained to estimate the appropriate coagulant dose are shown in Table 5.

\section{DISCUSSION}

As can be seen from the characteristics of the wastewater obtained and compared to Metcalf and Eddy, Inc. (1998) classification, wastewater is classified as gross domestic water of weak concentration; however, as shown in Table 3, wastewater has three parameters that override national and international Mexican standards.

According to the findings, the United States Environmental Protection Agency (1998) recommends that the turbidity of residual water at the exit of the clarification processes (coagulation-flocculation) be less than 1 NTU because filtration processes can cause pressure elevation and inadequate treatment; and the American Water Works Association (2001) recommends $1 \mathrm{NTU}$ as the average value and $5 \mathrm{NTU}$ as the maximum allowable value for clarified water. On the other hand, the European Union (1998) established 2 and 1 NTU, respectively, and the World Health Organization (WHO) suggests that the median turbidity of treated water is ideally less than 0.1 UNT for effective disinfection, although the WHO does not determine an admissible value of turbidity based on health criteria (WHO 2006, Montoya et al. 2011).

However, water turbidity can be considered as a parameter both in supply sources and in distribution processes and systems (Burlingame et al. 1998, Lusardi \& Consonery 1999, Letterman \& Viswanathan 2004), since it is a fast and inexpensive interpretation to interpret water quality (Burlingame et al. 1998).

Furthermore, turbidity is associated with the potential microbiological risk in water for human consumption.

In the case of coliforms, the microorganisms that make up this group, Escherichia, Enterobacter, Klebsiella, Serratia, Edwarsiella, and Citrobacter, live as independent saprophytes or as intestinal bacteria; fecal coliforms (Escherichia) are of intestinal origin (Canosa 1995), and their presence in water

Table 3: National and international maximum allowable limits.

\begin{tabular}{|lllll|}
\hline Parameter & Unit & $\begin{array}{l}\text { Average } \\
\text { amount }\end{array}$ & $\begin{array}{l}\text { MAL } \\
1\end{array}$ & $\begin{array}{l}\text { MAL } \\
2\end{array}$ \\
\hline Turbidity & NTU & 25.00 & - & 2 \\
$\begin{array}{l}\text { Fecal Coli- } \\
\text { forms }\end{array}$ & NMP.100mL & 4600.00 & 1000 & 1000 \\
$\begin{array}{l}\text { Total Coli- } \\
\text { forms }\end{array}$ & NMP.100mL & 24000.00 & - & 1000 \\
\hline
\end{tabular}

*MAL: Maximum Allowable Limit; **MAL 1: Maximum Allowable Limit NOM-001-SEMARNAT-1996; ***MAL 2: Maximum Allowable Limit Environmental Protection Agency 1998 indicates recent bacterial contamination and is an indicator of water body degradation and it was recommended by the United States Environmental Protection Agency (1998) and is based on studies that showed that they have a direct relationship with diseases associated with swimming in marine and freshwater environments (Arcos-Pulido et al. 2005).

The reduction of TTS and turbidity have a close relationship, as seen in Fig. 2. In Fig. 3 you can see that the TSS is present homogeneously in the samples. TSS is responsible for the gray color of domestic water, and when these waters are treated, the solids agglomerate and degrade because of gravity.

Similarly, Henckens et al. (2002) found that turbidity is a metric that is affected by a variety of factors, the most important of which are the properties of the suspended particles in the water, such as form, color, size, and organic and inorganic matter ratio (BOD/COD).

Studies such as those by Tomanovic \& Maksimovic (1996) and Henckes et al. (2002), show that there is a good correlation between TSS and turbidity in water bodies, while Bertrand-Krajewski (2004) discovered a linear relationship

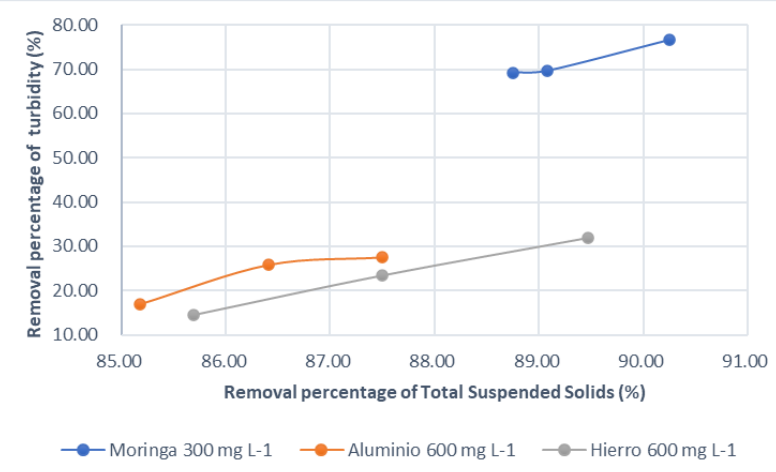

Fig. 2: Optimal per centages of pollutant removal.

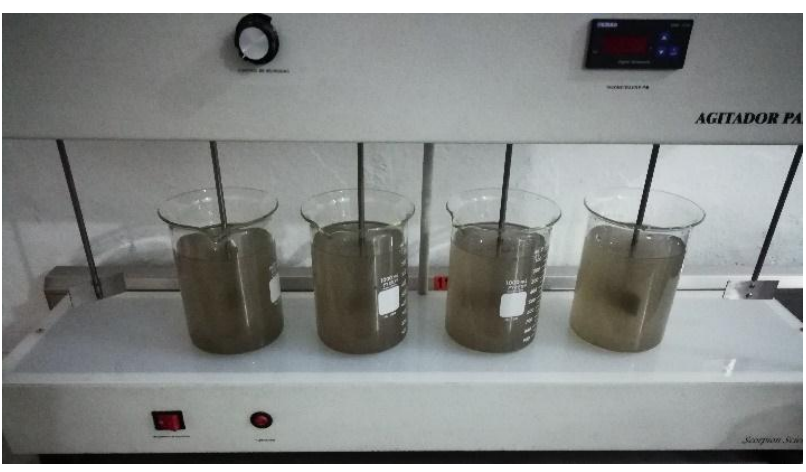

Fig. 3: Homogenization of domestic wastewater from Martínez de la Torre, Veracruz. 
between these parameters by analyzing unit networks in dry weather conditions and concluded that turbidity is a good indicator of TSS in wastewater, which we can confirm in Fig. 2 because increasing the percentage of turbidity removal is directly proportional to the reduction of TTS.

A 95 per cent mean analysis test was used to determine the significant differences (Fig. 4). It can be seen that the chemical coagulants (Industrial Aluminum Sulfate and Iron Sulfate Heptahydrate reactive grade) both had the same percentage of turbidity removal statistically at a concentration of $600 \mathrm{mg} . \mathrm{L}^{-1}$, whereas the use of Moringa oleifera at a concentration of $300 \mathrm{mg} . \mathrm{L}^{-1}$ has a different statistical percentage than this, being this the concentration used.

Subsequently, the removal percentage of TTS was observed by the same statistical method at $95 \%$ as shown in Fig. 5. The concentrations of chemical coagulants at 600 $\mathrm{mg} . \mathrm{L}^{-1}$ and Moringa oleifera at $300 \mathrm{mg} . \mathrm{L}^{-1}$ show statistically the same efficiencies, in addition to being the most efficient

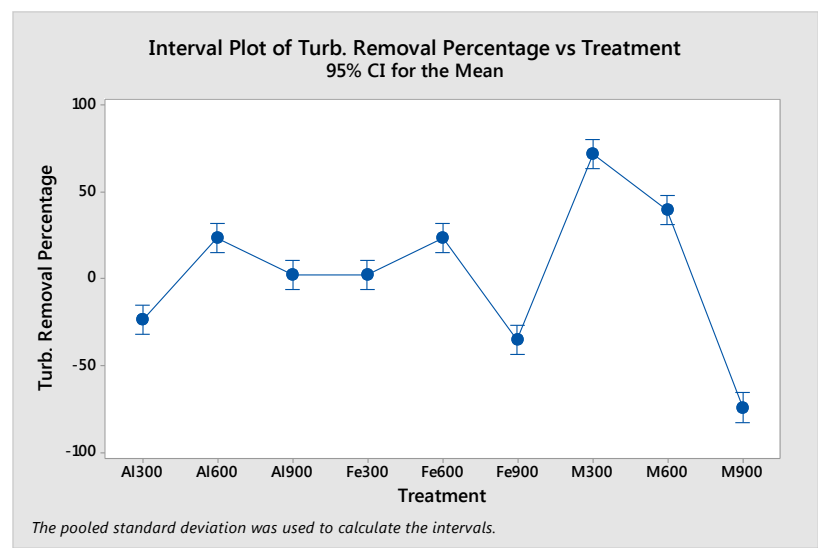

Fig. 4: Mean test with a 95\% confidence level for the determination of the optimal dose vs. turbidity. with removal averages of $86.36 \%, 87.55 \%$, and $89.36 \%$ respectively.

The effects of the coagulants were analyzed using surface tests to see how they affected the $\mathrm{pH}$ and conductivity of the samples before and after the coagulation-flocculation treatments proposed by chemical salts and Moringa oleifera powder. Fig. 6 shows that the turbidity removal and TSS percentages corresponding to Moringa oleifera powder show positive $\mathrm{pH}$ differences, whereas the results of the coagula-

Table 4: Treatments to determine the optimal concentration values per coagulant.

\begin{tabular}{|lccccl|}
\hline Treatment & $\mathrm{pH}$ & \multicolumn{2}{l}{ Coagulant [mg] } & $\begin{array}{l}\text { Sample [1000 } \\
\mathrm{mL}]\end{array}$ \\
\hline Moringa oleifera & 7.0 & 300 & 600 & 900 & 1000 \\
Aluminum sulfate & 7.0 & 300 & 600 & 900 & 1000 \\
Iron sulfate & 7.0 & 300 & 600 & 900 & 1000 \\
\hline
\end{tabular}

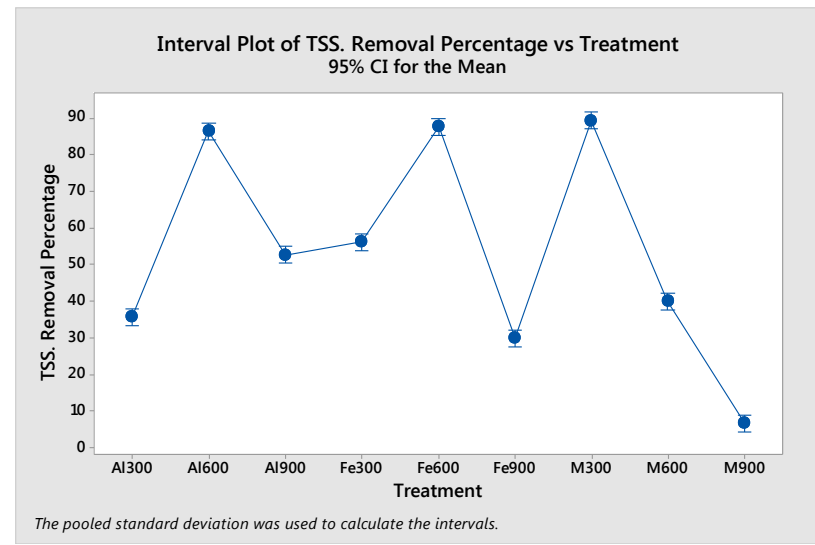

Fig. 5: Mean test with a 95\% confidence level for the determination of the optimal dose vs TSS.

Table 5: Per centage of removal of turbidity and total suspended solids.

\begin{tabular}{|c|c|c|c|c|c|c|c|}
\hline \multirow{2}{*}{$\begin{array}{l}\text { Treatment } \\
\text { Moringa oleifera }\end{array}$} & \multirow{2}{*}{$\begin{array}{l}\text { Concentration } \\
300\end{array}$} & \multicolumn{3}{|c|}{ Turbidity removal per centage } & \multicolumn{3}{|c|}{ TSS removal rate } \\
\hline & & 69.23 & 69.60 & 76.68 & 88.75 & 89.08 & 90.25 \\
\hline & 600 & 28.79 & 31.43 & 58.70 & 38.75 & 40.14 & 41.11 \\
\hline & 900 & -74.79 & -73.85 & -73.3 & 6.54 & 6.66 & 6.80 \\
\hline \multirow[t]{3}{*}{ Aluminum sulfate } & 300 & -25.75 & -24.74 & -20.54 & 33.93 & 36.36 & 36.93 \\
\hline & 600 & 17.03 & 25.82 & 27.52 & 85.18 & 86.41 & 87.50 \\
\hline & 900 & 2.02 & 2.50 & 2.56 & 50.00 & 50.72 & 57.25 \\
\hline \multirow[t]{3}{*}{ Iron sulphate } & 300 & 1.87 & 1.89 & 3.79 & 54.27 & 56.25 & 57.89 \\
\hline & 600 & 14.53 & 23.44 & 31.90 & 85.69 & 87.50 & 89.47 \\
\hline & 900 & -38.18 & -36.75 & -29.88 & 28.15 & 30,71 & 30,89 \\
\hline
\end{tabular}


Surface Plot of pH difference vs TSS. Removal Per, Turb. Removal Pe

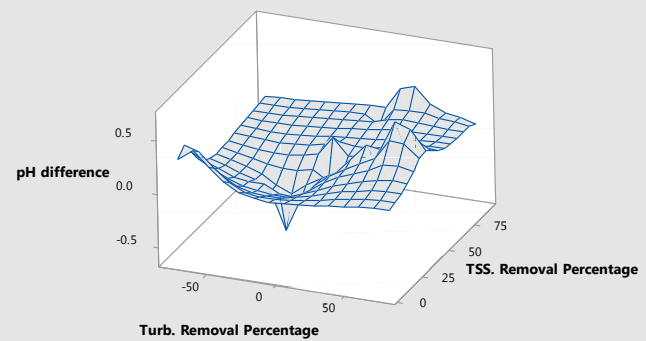

Fig. 6: Test of surfaces applied at $\mathrm{pH}$ and removal of contaminants after treatment.

tion tests with aluminum and iron show negative peaks, due to the pretreatment with aluminum.

Fig. 7 shows that chemical salts tend to increase the conductivity of treated wastewater due to the presence of metal ions. Sandoval \& Laines (2013) compared the coagulation efficiency of three types of solutions obtained from Moringa oleifera seeds and aluminum sulphate, finding that moringa treatments did not change the chemical properties of the treated water, which is confirmed in said work, since the said solute did not change the properties of conductivity and $\mathrm{pH}$ during experimentation, whereas aluminum sulphate, as a chemical salt with metal ions, tends to acidify the water.

\section{CONCLUSION}

For the treatment of wastewater from the sewage system in Martnez de la Torre, Veracruz, moringa seed powder is effective as a flocculant and natural coagulant. The appropriate dose of moringa powder for urban wastewater from Martínez de la Torre, Veracruz is $300 \mathrm{mg} . \mathrm{L}^{-1}$. Because it did not present free sulfate ions in the medium after the decantation period, the optimal dose of Moringa oleifera obtained the maximum percentage of turbidity degradation (71.84 per cent) in 15 minutes of stirring and 1 hour of rest. The decrease in Total Suspended Solids from the moringa coagulant was statistically similar to that obtained by aluminum and iron salts.

Moringa oleifera seed powder does not produce changes in control parameters such as $\mathrm{pH}$ and conductivity, whereas aluminum and ferric salts in this experiment reported $42 \%$ and $56 \%$ due to the presence of metal ions in the wastewater.

The use of Moringa oleifera powder is a natural, efficient, and easy to use as an alternative. This type of unconventional treatment will be able to recover the water used within the metropolitan area of Martínez de la Torre and improve the
Surface Plot of Conduc.differenc vs TSS. Removal Per, Turb. Removal Pe

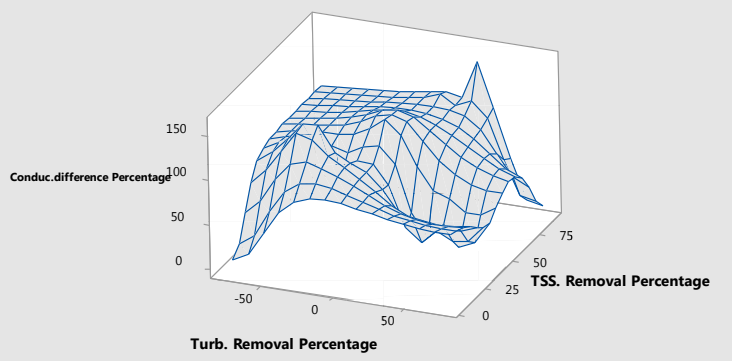

Fig. 7: Surface test applied to the percentage of difference in conductivity and removal of contaminants after treatment.

quality of the water of the Filobobos river, in addition, to contributing to the reduction of sludge.

\section{ACKNOWLEDGEMENTS}

We are grateful to the Tecnológico Nacional de México/Instituto Tecnológico Superior de Martínez de la Torre and the Tecnológico Nacional de México, in addition to the teachers Edwin Daniel Méndez Cruz, Leonides Sánchez Mota and the students Rigo Adalberto Ruiz Alberto and Ana Cristina Sandría, for their support and dedication in taking samples.

\section{REFERENCES}

Arcos-Pulido, M.P., Ávila de Navia, S.L., Estupiñan-Torres, S.M. and Gómez-Prietp, A.C. 2005. Microbiological indicators of contamination of water sources. Nova-Sci. Pub., 3(4): 69-79.

APHA-AWWA-WPCF 1998. Standards Methods For the Examination of Water and Wastewater. 20th Edition, USA.

American Water Works Association 2001. Self-Assessment for Treatment Plant Optimization. International Edition, Denver.

Bertrand-Krajewski, J.L. 2004. TSS concentration in sewers was estimated from turbidity measurements by means of linear regression accounting for uncertainties in both variables. Water Sci. Technol., 50(11): 81-88

Burlingame, G.A., Pickel, M.I.J. and Roman, J.T. 1998. Practical application of turbidity monitoring. J. AWWA, 90(8): 57-69.

Canosa, A. 1995. Bacteriological Indicators of Eutrophication in the Chuza, Neusa, and Tominé Reservoirs, and the Chingaza Lagoon. Bogota Colombia. The Jorge Tadeo Lozano University of Bogotá Foundation, Center for Scientific Research.

European Union. 1998. Council Directive 98/83/EC. Relating to the quality of water intended for human consumption.

Henckens, G.J.R., Veldkamp, R.G. and Schuit, T.D. 2002. On monitoring of turbidity in sewers. Amerian Society of Civil Engineers, Proceedings of the Ninth International Conference on Urban Drainage, Portland, 8-13 September.

Letterman, R.D., Johnson, C.E. and Viswanathan, S. 2004. Low-level turbidity measurements: A comparison of instruments. J. AWWA, 96(8): 125-137. 
Lusardi, P.J.Y. and Consonery, P.J. 1999. Factors affecting filtered water turbidity. J. AWWA, 91(12): 28-40.

Metcalf and Eddy, Inc. 1998. Wastewater Engineering. Treatment, Discharge, and Reuse. McGraw Hill Publisher, Mexico.

Montoya, C., Loaiza, D., Torres, P., Hernán-Cruz, C.Y. and Escobar, J.C. 2011. Effect of the increase in the turbidity of raw water on the efficiency of conventional purification processes. J. Sch. Eng. Antioquia, 16: 137-148.

Norde, W. 2011. Colloids and Interfaces in Life Sciences and Bionanotechnology. 2nd Edition, CRC Press, Boca Raton, FL.

Rozkosný, M., Kriska, M., Sálek, J., Bodík, I. and Istenic, D. 2014. Natural Technologies of Wastewater Treatment. Global Water Partnership, Central and Eastern Europe, p. 138.

Tomanovic, A. and Maksimovic, C. 1996. Improved modeling of suspended solids discharges from asphalt surface during the storm event. Water Science and Technology, 33(4-5): 363-369.
Sandoval, M. and Laines, J. 2013. Moringa oleifera is an alternative to replacing metallic coagulants in surface water treatment. Eng. FI-UADY Acad. Rev., 17(2): 93-10.

Solís-Silvan, R., Laines-Canepa, L.C. and Hernández-Barajas, J.R. 2012. Mixtures with coagulating potential to clarify surface water. Rev. Inv. Cont. Amb., 28(3): 229-236

The United States Environmental Protection Agency. 1998. Optimizing water treatment plant performance using the composite correction program. EPA/625/6-91/027. USEPA, Washington, D.C.

Vásquez, O. 1994. Extraction of Natural Coagulants from Nopal and Application in Clarification of Surface Water [Thesis]. Universidad Autónoma de Nuevo León, Monterrey, México, pp. 28-57.

World Health Organization (WHO). 2006. Guidelines for Drinking Water Quality. Third Edition. Volume 1. WHO, Geneva, Switzerland. 